\title{
P309: Knowledge and occupational exposure to blood and body fluids among medical students
}

\author{
L Markovic-Denic \\ From 2nd International Conference on Prevention and Infection Control (ICPIC 2013) \\ Geneva, Switzerland. 25-28 June 2013
}

\section{Introduction}

Medical students, as other health care workers, are at risk for occupational needlestick injuries (NSIs) which can result in exposure to blood-borne pathogens and substantial health consequences.

\section{Objectives}

To determine the frequency of NSIs and the knowledge, attitudes and perception of risks of blood-borne diseases of the medical students.

\section{Methods}

The cross-sectional study was conducted among four and sixth-year students of the Faculty of Medicine, Belgrade. Data were obtained using a self-reported anonymous questionnaire whichincluded social-demographic data, NSIs, level of knowledge, risk-awareness, reporting behavior and vaccination status against hepatitis $B$.

\section{Results}

The questionnaire was filled-in and returned by $80.9 \%$ of fourth-year and $63.1 \%$ of sixth-year medical students. The study group included more female students $(69.3 \%$ in fourth and $67,1 \%$ in final year). Out of all, $8.4 \%$ fourth and 9.8\% sixth-years students had at least one accident ( $\mathrm{p}>$ 0.05). The largest number of accidents occurred during blood-taking practices. The accident was not reported at all by $43.3 \%$ students. Overall, final year medical students were significantly more knowledgeable regarding sharps injuries than the fourth year ( $\mathrm{p}<0.01$ ). Only $25.9 \%$ of all students, without differences according to year of studing, were vaccinated against hepatitis $B$, nevertheless that vaccine is free for them. About two-tiers of students recognized the risk of hepatitis B transmission.

Institute of Epidemiology, Faculty of Medicine, University of Belgrade, Belgrade, Serbia

\section{Conclusion}

This study demonstrated that intensive education which can improve the knowledge about the transmission of bloodborne infections and reduce the number of needlestick injuries of medical students must be implemented.

\section{Disclosure of interest}

None declared.

Published: 20 June 2013

doi:10.1186/2047-2994-2-S1-P309

Cite this article as: Markovic-Denic: P309: Knowledge and occupational

exposure to blood and body fluids among medical students.

Antimicrobial Resistance and Infection Control 2013 2(Suppl 1):P309.
Submit your next manuscript to BioMed Central and take full advantage of:

- Convenient online submission

- Thorough peer review

- No space constraints or color figure charges

- Immediate publication on acceptance

- Inclusion in PubMed, CAS, Scopus and Google Scholar

- Research which is freely available for redistribution
C Biomed Central

\section{Ciomed Central}

